\title{
Effectiveness of Virtual Bronchoscopy in Evaluation of Centrally Located Lung Cancer
}

\section{Santral Akciğer Kanserinin Değerlendirilmesinde Sanal Bronkoskopinin Etkinliği}

(i) Dilek Hacer ÇEŞME

Bezmialem Vakıf University Faculty of Medicine, Department of Radiology, İstanbul, Turkey

\begin{abstract}
Objective: The aim of this study was to compare virtual bronchoscopy (VB) with multi-slice CT (MSCT) in the diagnosis of centrally located lung cancer and to investigate the effectiveness of VB in the diagnosis of the radiologist.

Methods: These patients had central lung mass detected during thorax tomography and were diagnosed as having centrally located lung cancer by histopathological examination. Detection and localization of lesions were determined by MSCT and VB. In addition, the evaluation time was determined in seconds with an electronic stopwatch.
\end{abstract}

Results: The mean age of 32 patients included in the study was $58.14 \pm 15.09$. Centrally located squamous cell carcinoma $(n=19)$ and small cell carcinoma $(\mathrm{n}=13)$ were included. Eighteen $(54.8 \%)$ patients were male and $14(47.6 \%)$ were female. All patients diagnosed as having centrally located lung cancer detected by MSCT were also detected by VB (100\%). In the evaluation of patients with MSCT and VB; obstruction and/or lesion and their localization completely overlapped. The mean duration of MSCT evaluation of the patients was determined as $58.7 \mathrm{sec}$, and the mean duration of VB assessment was $549.9 \mathrm{sec}$. The mean VB evaluation duration was found to be statistically significantly longer than the mean MSCT evaluation duration.

Conclusion: Virtual bronchoscopy does not provide a significant additional contribution to MSCT in the diagnosis of centrally located malignant lung tumor. We think that using VB for diagnosis and navigation will be important in terms of efficiency especially in selected patients due to its low specificity and high sensitivity.

Keywords: Virtual bronchoscopy, multislice CT, lung cancer

\section{ÖZ}

Amaç: Santral yerleşimli akciğer kanseri tanısında sanal bronkoskopi uygulamasının çok kesitli BT (ÇKBT) ile karşılaştırmak ve radyoloğun tanıya ulaşmasında sanal bronkoskopinin (SB) etkinliğini araştırmak.

Yöntemler: Otuz iki hasta çalışmaya dahil edildi. Bu hastalarda toraks tomografisi sırasında santral akciğer kitlesi saptanmıştı ve histopatolojik inceleme ile santral akciğer kanseri tanısı konmuştu. ÇKBT ve SB ile lezyonların tespiti ve lokalizasyonları sağlandı. Ayrıca elektronik kronometre ile değerlendirme süresi saniye olarak tespit edildi.

Bulgular: Çalışmaya alınan 32 hastanın yaş ortalaması 58,14 15,09 idi. Santral yerleşimli skuamöz hücreli karsinom $(n=19)$ ve küçük hücreli karsinom ( $\mathrm{n}=13)$ çalışma kapsamına alındı. Hastaların 18’i $(\% 54,8)$ erkek, 14 ü $(\% 47,6)$ kadın idi. ÇKBT ile tespit edilen santral yerleşimli akciğer kanseri tanısı alan hastaların tamamında kanser SB ile de tespit edildi (\%100). Hastaların ÇKBT ve SB değerlendirmelerinde obstrüksiyon ve/veya lezyon varlığı ve lokalizasyonu tamamen örtüşmektedir. Hastaların ÇKBT değerlendirme sürelerinin ortalaması $58,7 \mathrm{sn}$, SB değerlendirme süresi ise ortalama 549,9 sn olarak belirlendi. SB değerlendirme sürelerinin ortalaması, ÇKBT değerlendirme sürelerinin ortalamalarından istatistiksel olarak anlamlı derecede uzun bulundu ( $\mathrm{p}=0,0001)$.

Sonuç: Sanal bronkoskopi, santral malign akciğer tümörü tanısında ÇKBT'ye belirgin ek katkı sağlamamaktadır. SB'nin duyarlılığının yüksek olmasına rağmen özgüllüğünün düşük olması nedeniyle özellikle seçilmiş hastalarda tanı ve navigasyon amacıyla kullanılmasının verimlilik açısından önemli olacağını düşünmekteyiz.

Anahtar Sözcükler: Sanal bronkoskopi, çok kesitli BT, akciğer kanseri

Address for Correspondence: Dilek Hacer ÇEŞME, Bezmialem Vakıf University Faculty of Medicine, Department of Radiology, İstanbul, Turkey

E-mail: dhcesme@bezmialem.edu.tr ORCID ID: orcid.org/0000-0002-3869-0524 


\section{Introduction}

Lung cancer ranks first among cancer types that cause death in men and second in women. The 5-year survival in the early stage of the disease ranges from $38 \%$ to $67 \%$ and $1 \%$ to $8 \%$ in the late stage (1).

The first diagnostic method used in the diagnosis of lung cancer is postero anterior (PA) X-ray and Thorax computed tomography (CT). Centrally located lung cancers are usually diagnosed by direct bronchoscopy and biopsy. With advances in CT technology and three-dimensional imaging, obtaining sagittal and coronal reformat images from axial sections with the help of thin sections increases the diagnostic accuracy. Multiplanar imaging-guided evaluation and three-dimensional perception make it easier to master anatomical structures. With the development of gantry systems in slip-ring geometry in CT devices, it is possible to obtain information from a certain volume. Volume information can be transformed into three-dimensional images with special software and thus virtual bronchoscopic (VB) examinations can be performed. It is possible to provide an anatomically realistic view of the tracheobronchial tree lumen. Although VB can evaluate the wall and lumen of the respiratory tract, it can guide the lesion with its navigation feature (2-5).

Our aim in our study was to compare virtual bronchoscopy application with multi-slice CT (MSCT) in the diagnosis of centrally located lung cancer and to investigate the effectiveness of virtual bronchoscopy in the diagnosis

\section{Method}

\section{Patient Selection}

Among the patients who underwent thoracic tomography, 32 patients diagnosed as having central lung cancer by histopathological examination were evaluated. Centrally located squamous cell carcinoma $(n=19)$ and small cell carcinoma $(n=13)$ were included in the study. Patients with peripheral lung cancer were not included in the study.

\section{Thorax Multi-Slice CT (MSCT) Imaging}

Somatom Sensation 40 (Siemens MedicalSystems, Germany) MSCT device was used. The imaging was performed in supine position at axial plane with a section thickness of $0.6 \mathrm{~mm}$, and with parameters of $100 \mathrm{mAs}$ on average and $120 \mathrm{kV}$, using contrast agent. In the "lungcare" program used, the whole thorax was scanned in approximately 10 seconds with a single breath, with the pitch factor (table speed/cross section collimation $\mathrm{x}$ number of detectors) being 1.4. CT images were reconstructed with a thickness of $2 \mathrm{~mm}$ and a reconstruction interval of $1 \mathrm{~mm}$. All image data were sent electronically to a separate workstation (Leonardo, Siemens, Erlanger, Germany) via the network for interpretation. Axial CT images and coronal-sagittal multiplanar reformatted images were evaluated with standard lung window settings (level, -600 HU; width, $1200 \mathrm{HU}$ ) and mediastinal window settings (level, $40 \mathrm{HU}$; width, $400 \mathrm{HU}$ ).
Tracheobronchial tree was evaluated by imaging the following structures: The trachea, right main bronchus, right upper lobe bronchus, right upper lobe antheriopical and posterior segment entrances, intermediary bronchus, right middle lobe bronchus, right middle lobe medial and lateral segment entrances, right lower lobe bronchus, right lower lobe superior, anterobasal, mediobasal, laterobasal and posterobasal segment entrances, left main bronchus, left upper lobe bronchus, left upper lobe apicoposterior and anterior segment entrances, lingula bronchus, lingula superior and inferior segment entrances, left lower lobe bronchus, and left lower lobe superior, posterobasal, laterobasal and anteromediobasal segment entrances. The region and/ or regions where obstruction or lesions were detected were determined. Additionally, the evaluation time in seconds was noted with the electronic stopwatch.

\section{Virtual Bronchoscopy}

For reconstruction of the images, $512 \times 512$ matrix gray-scale images were obtained using standard and wide reconstruction algorithms $\left(360^{\circ}\right.$ linear interpolation). Image segmentation was done based on the threshold value. For threshold voxel values, the lower limit was accepted as -500 and the upper limit was accepted as 800 Hounsfield units (HU). These values were chosen in such a way that they could distinguish the mucosal structure and soft tissues within the airways. VB images obtained with a computer program called "Shaded Surface Display (SSD) b" were simultaneously evaluated with axial CT, coronal and sagittal multiplanar reformation (MPR) images on a computer screen divided into four equal quadrants in multi-view mode. Tracheobronchial tree navigation was carried out in "flythrough" mode involving the trachea, right main bronchus, right upper lobe bronchus, right upper lobe anteriorapical and posterior segment entrances, intermediary bronchus, right middle lobe bronchus, right middle lobe medial and lateral segment entrances, right lower lobe bronchus, right lower lobe superior, anterobasal, mediobasal, laterobasal and posterobasal segment entrances, left main bronchus, left upper lobe bronchus, left upper lobe apicoposterior and anterior segment entrances, lingula bronchus, lingula superior and inferior segment entrances, left lower lobe bronchus, and left lower lobe superior, posterobasal, laterobasal and anteromediobasal segment entrances. The regions and/ or regions where obstruction or lesions were detected were determined. In addition, the evaluation time in seconds was noted with the electronic stopwatch.

\section{Statistical Analysis}

Statistical analyzes in this study were performed using the NCSS (NumberCruncher Statistical System) Statistical Software (Utah, USA) package program. In addition to descriptive statistical methods (mean, standard deviation) in the evaluation of the data, independent t-test was used for the comparison of paired groups. The results were evaluated at the significance level of $\mathrm{p}<0.05$.

\section{Results}

The mean age of 32 patients included in the study was 58.14 15.09 . Eighteen (54.8\%) patients were male and 14 
(47.6\%) were female. All of the patients diagnosed as having centrally located lung cancer detected by MSCT were detected by VB (100\%) (Figure 1). Presence and localization of obstruction and/or lesion in MSCT and VB evaluations of the patients completely overlapped (Figures 2, 3). The mean MSCT evaluation time of the patients was 58.7 seconds, and the mean time for VB evaluation was 549.9 seconds. The mean of the VB evaluation times was found to be statistically significantly longer than the mean of MSCT evaluation times ( $\mathrm{p}=0.0001)$.

\section{Discussion}

Studies in the field of CT virtual endoscopy were first reported by Vining et al. $(6,7)$. Researchers presented the first studies on both the tracheobronchial system, the colon, and the bladder $(6,7)$. With the developments in software programs and detector technologies, diagnostic use has become routine today.

Virtual bronchoscopy, colonoscopy and cystoscopy methods are frequently used in our routine practices today. Virtual bronchoscopy has high sensitivity in evaluating stenoses in the tracheobronchial tree. However, the extrinsic-intrinsic differentiation of stenoses cannot be made with VB alone. For this, axial, coronal, and sagittal reformatted images should also be carefully examined (8-10). Accuracy rates in detecting stenoses were found to be $98 \%$ for VB, $96 \%$ for sagittal reformatted images and $96 \%$ for coronal reformed images in a study conducted with MSCT. However, the sensitivity was found to be $95 \%$ in axial images, while it was found to be $90 \%$ in $\operatorname{VB}(8,10)$.
Pathological events affecting the central airways consist of a heterogeneous group of diseases. Focal changes can be classified as malignant (non-small cell carcinoma, small cell carcinoma), benign (papilloma, hamartoma, carcinoid) and nonneoplastic diseases. Diffuse changes are enlargement, narrowing and tracheobronchomalacia in the airways (3-5). Mucosal layer can be seen directly with direct bronchoscopy. VB provides important information in evaluating the walls of the airways (3-5).

In our study, a retrospective evaluation was made to reveal whether the VB facilitated the radiologist's work in daily practice in the diagnosis of centrally located lung cancer compared with the MSCT. In the MSCT and VB evaluations of the patients, it was found that the presence of obstruction and/or lesion and the determination of localization completely overlapped. The addition of VB to MSCT did not add any additional contribution to diagnostic accuracy of centrally located lung cancer. However, the mean MSCT evaluation time of the subjects included in the study were 58.7 seconds, and the mean VB evaluation time was 549.9 seconds, and the mean VB evaluation time was considerably longer than the mean MSCT evaluation time. Multiplanar evaluation of malignant lesions in MSCT takes less time than VB. The imaging duration can be seen as a disadvantage for VB. In the study conducted by Hoppe et al. (8) to evaluate the stenoses in the tracheobronchial tree, it was emphasized that the sensitivity in axial MSCT was higher than VB, and that the VB did not provide significant superiority to MPR images in terms of diagnostic accuracy. However, Hoppe et al. (8) did not consider the evaluation duration in their study.

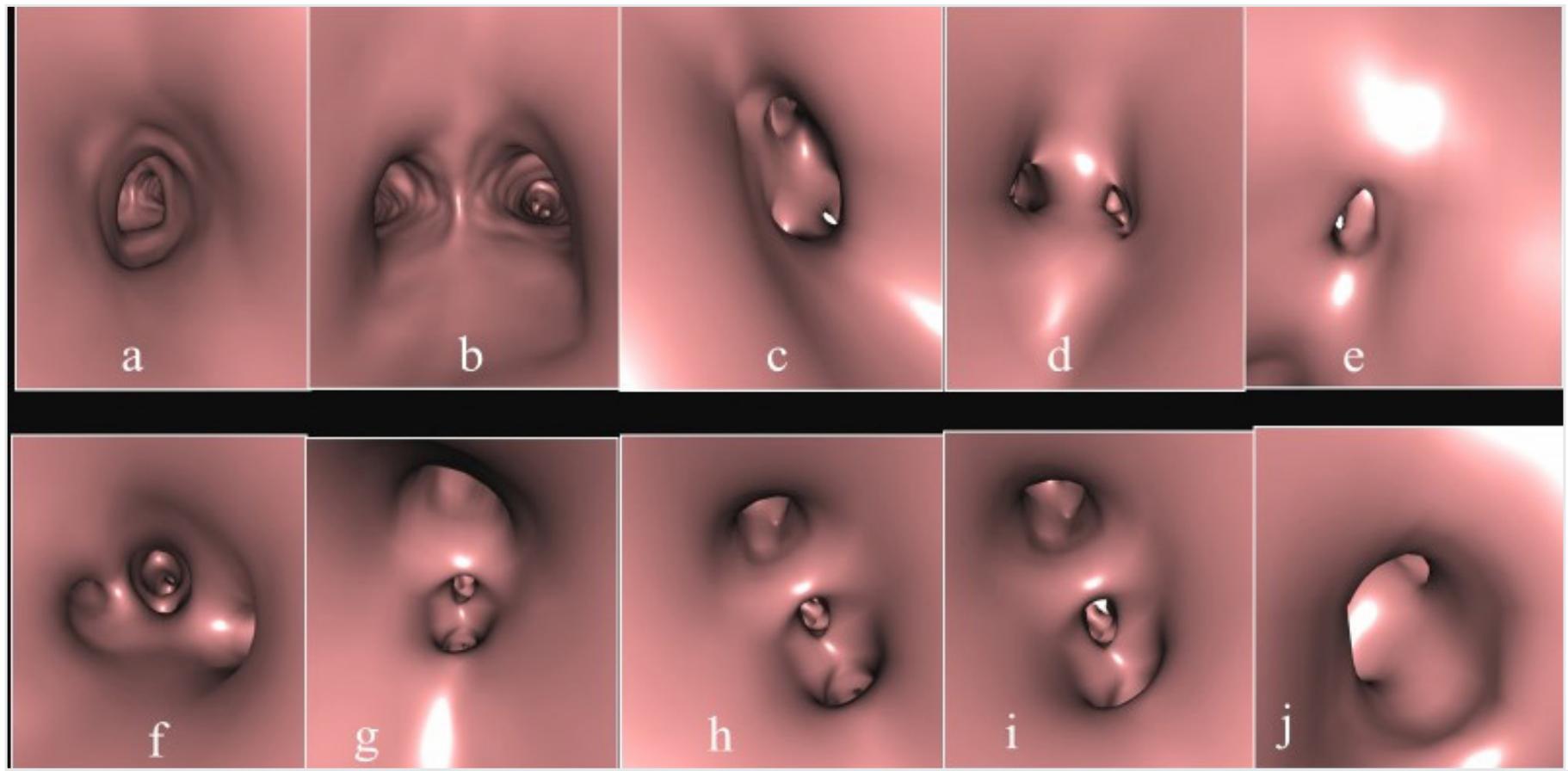

Figure 1. VB showing the airways. Trachea (a), Right and left main bronchus entrances (b), Right upper lobe anterior, posterior and apical segment entrances (c), Right lung middle lobe medial and lateral segment entrances (d), Right lung lower lobe superior segment entrance (e), Right lung lower lobe basal segment entrance (f), Left lung upper lobe bronchus, view of second carina (g), Left lung upper lobe anterior and apicoposterior segment entrances (h), Left lung lingula superior and inferior segment entrances (i), Left lung lower lobe superior segment entrance (j)

VB: Virtual bronchoscopy 
In the evaluation of endobronchial lesions, measurements such as bronchial diameter, lesion size and stenosis length can be made with MPR images. But specificity of VB is low. Differentiation of bronchial cancer, mucous plaque, benign tumor, clot, foreign body cannot be made, so its selectivity is low. In a study, it was reported that the sensitivity of $\mathrm{VB}$ in the evaluation of endobronchial tumors was high (88\%) and its specificity was low (50\%) (11).

VB navigation (VBN) system is commonly used today. It consists of two phases; prebroncoscopic planning phase in which $\mathrm{VB}$ images of the bronchial tree navigating to the target lesion are created and guidance phase in which the navigation of

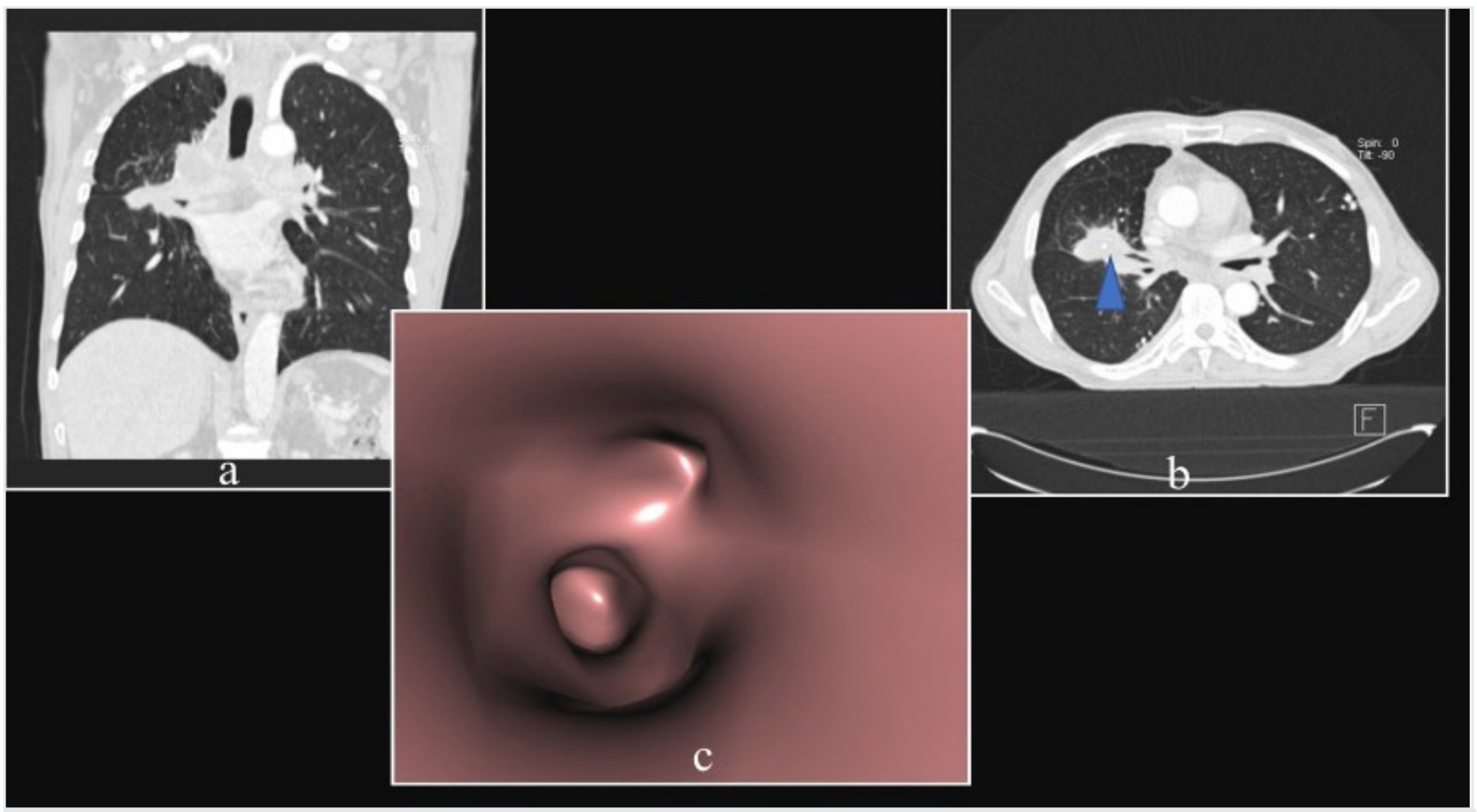

Figure 2. A 58-year-old male patient diagnosed as having centrally located squamous cell carcinoma. Coronal MPR (a), axial MSCT (arrowhead) (b) and VB images (c) showing centrally located mass lesion obstructing the right middle lobe lateral segment MPR: Multiplanar reformation, MSCT: Multi-slice CT, VB: Virtual bronchoscopy

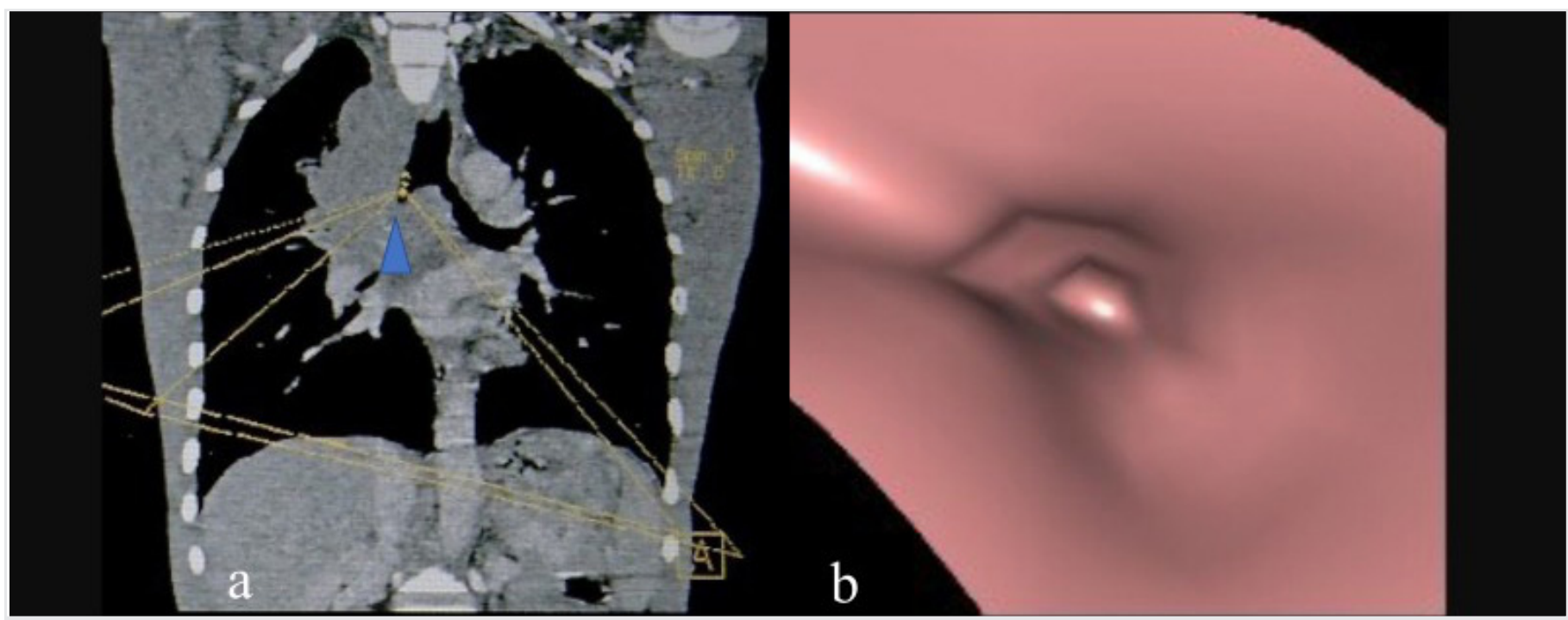

Figure 3. A 63-year-old male patient diagnosed as having small cell carcinoma. Coronal MPR (a), MSCT and SB images (b) showing a mass lesion (arrowhead) obstructing the right main bronchus completely

MPR: Multiplanar reformation, MSCT: Multi-slice CT, VB: Virtual bronchoscopy 
bronchoscope to the target lesion is performed using the VBN system (12-14). VB is very important, especially in terms of preoperative mapping and navigation $(15,16)$. In addition, the most reliable CT finding in foreign body aspiration in children is the visualization of the foreign body in the tracheobronchial tree. The location of the foreign body can be easily demonstrated noninvasively with VB (17). It was reported that VB had high sensitivity $(90 \%)$ and specificity $(100 \%)$ in foreign body aspiration (17).

In our study, no difference was found in terms of detection and localization of lesions with VB and MSCT. However, we think that there is a significant difference in terms of loss of time in reaching the diagnosis between VB and MSCT and therefore, the use of $\mathrm{VB}$ in intensive radiology practice will be beneficial in selected patients. The use of VB as a guide in some invasive procedures, use in the evaluation of patients after surgical interventions such as transplantation, lung resection or repair of post-traumatic airway anastomoses, use in the evaluation of stenosis in pediatric patients with esophageal atresia, distal tracheoesophageal fistula, $\mathrm{H}$-type fistula and bronchial anastomosis, use in the evaluation of lobar or segmental bronchial abnormalities and use in the evaluation of the distal part of the obstruction in the patient population with high rates of obstruction would be appropriate for efficiency.

\section{Study Limitations}

Among the limitations of the study, the small number of patients seemed to be the most important limitation. The second limitation was that benign lesions and peripheral lung lesions were not included in the study. The third limitation was that thorax CT and VB were not evaluated by different observers, so whether there was any difference between observers was not investigated.

\section{Conclusion}

VB does not significantly contribute to MSCT in the diagnosis of centrally located malignant lung tumor. We think that it will be important in terms of efficiency to use VB for diagnosis and navigation, especially in selected patients due to its low specificity despite its high sensitivity.

\section{Ethics}

Ethics Committee Approval: 2021/0226

Informed Consent: Informed consent was not obtained as the study design was retrospective.

Peer-review: Externally peer reviewed.

Financial Disclosure: The authors declared that this study received no financial support.

\section{References}

1. Reynisson PJ, Leira HO, Hernes TN, Hofstad EF, Scali M, Sorger $\mathrm{H}$, et al. Navigated Bronchoscopy A Technical Review. J Bronchol Intervent Pulmonol 2014;21:242-64.
2. Adamczyk M, Tomaszewski G Naumczyk P, Kluczewska E, Waleck J. Usefulness of computed tomography virtual bronchoscopy in the evaluation of bronchi divisions. Pol J Radiol 2013;78:30-41.

3. Barnes D, Chacoff JG, Benegas M, Perea RJ, de Caralt TM, Ramirez J, et al. Central airway pathology: clinic features, CT findings with pathologic and virtual endoscopy correlation. Insights Imaging 2017;8:255-70.

4. Jugpal TS, Garg A, Sethi GR, Daga MK, Kumar J. Multi-detector computed tomography imaging of large airway pathology: A pictorial review. World J Radiol 2015;28:459-74.

5. McInnis MC, Weisbrod G, Schmidt H. Advanced Technologies for Imaging and visualization of the tracheobronchial tree from computed tomography and MRI to Virtual Endoscopy. Thorac Surg Clin 2018;28:127-37.

6. Vining DJ, Gelfland DW, Bechtold RE, et. al. Technical feasibility of colon imaging with helical CT and virtual reality. AJR 1994;162:104.

7. Vining DJ, Zagoria RJ, Liu K, Stelts D. CT cystoscopy: an innovation in bladder imaging. AJR 1996; 166:409-10.

8. Hoppe H, Walder B, Sonnenschein M, Vock P, Dinkel H-P. Multidedector CT virtual bronchoscopy to grade tracheabronchial stenosis. AJR 2002;178:1195-2000.

9. Das KM, Lababidi H, Dandan SA, Raja S, Sakkijha H, Al Zoum M, et al. Computed Tomography virtual bronchoscopy: Normal variants, pitfalls, and spectrum of commonand rare pathology. Canadian Association of Radiologists Journal 2015;66:58-70.

10. Wever VD, Bogaert J, Verschakelen JA. Virtual bronchoscopy: Accuracy and usefulness. Semin Ultrasound CT MRI 2005;26:36473

11. Barış Bakir B, Tuzun U, Terzibasioglu E, Dursun M, Güven K, Salmaslioğlu A, et al. Endobronşiyal tümörlerde çok kesitli BT sanal bronkoskopinin tanısal etkinliği. Tüberküloz ve Toraks Dergisi 2008;56:43-9.

12. Landseurau RJ, Hazelrigg SR, Mack MJ, Fitzgibbon LD, Dowling RD, Acuff TE, et al. Thoracoscopic mediastinal lymph nodes ampling: useful for mediastinal lymph node stations in accesible by cervical mediastinoscopy. J Thorac Cardiovasc Surg 1993;106:554-8.

13. Boiselle PM. Multislice helical CT of the central airways. Radiol Clin N Am 2003;41: 561-74.

14. Kemp SV. Navigation bronchoscopy. Respiration 2019 (10). Doi: 10.1159/000503329.

15. Kitano K, Sato M. Latest update about virtual-assisted lung mapping in thoracic surgery. Ann Transl Med 2019;7:36.

16. Sato M, Kuwata T, Kitamura A, Misawa K, Imashimizu K, Yamanashi $\mathrm{K}$, et al. The role of virtual-assisted lung mapping in there section of ground glass nodules. J Thorac Dis 2018;10:2638-47.

17. Dogan S, Coskun A, Yikilmaz A, Hasdiraz L, Tahan F. The Value of Low-dose multidetector CT and virtual bronchoscopy findings in pediatric patients with suspected foreign body aspiration. Erciyes Tip Dergisi (Erciyes Medical Journal) 2008;30:78-83. 